\begin{tabular}{|l|l|l|}
\hline \multicolumn{2}{|c|}{ PublisherInfo } \\
\hline \hline PublisherName & $:$ & BioMed Central \\
\hline \hline PublisherLocation & $:$ & London \\
\hline \hline PublisherImprintName & $:$ & BioMed Central \\
\hline \hline
\end{tabular}

\title{
Heparin-induced thrombocytopenia
}

\begin{tabular}{|l|l|l||}
\hline \multicolumn{2}{|c||}{ ArticleInfo } \\
\hline \hline ArticleID & $:$ & 4306 \\
\hline \hline ArticleDOI & $:$ & $10.1186 /$ ccf-2001-73302 \\
\hline \hline ArticleCitationID & $:$ & 73302 \\
\hline \hline ArticleSequenceNumber & $:$ & 17 \\
\hline \hline ArticleCategory & $:$ & Paper Report \\
\hline \hline ArticleFirstPage & $:$ & 1 \\
\hline \hline ArticleLastPage & $:$ & 3 \\
\hline \hline & & RegistrationDate : 2001-12-4 \\
ArticleHistory & $:$ & Received \\
\hline ArticleCopyright & $:$ 2001-7-2 \\
\hline \hline ArticleGrants & $:$ & OnlineDate \\
\hline \hline ArticleContext & $:$ & 1305455 \\
\hline \hline
\end{tabular}


Richard Venn, ${ }^{\text {Aff1 }}$

Aff1 Worthing Hospital, UK

Keywords

Antibody, heparin, thrombocytopenia, thrombosis

\section{Context}

Heparin-induced thrombocytopenia (HIT) is a relatively common antibody-mediated drug reaction in the ICU and paradoxically is associated with thrombosis. Diagnosis is based on finding circulating heparin-dependent antibodies. Onset is usually about a week after the start of heparin therapy (typicalonset HIT), but it can occur more rapidly if the patient has previously been treated with heparin (rapidonset HIT). This study identifies the timing of onset of HIT in relation to present and previous heparin treatment.

\section{Significant findings}

Of patients with typical-onset HIT, 28\% (47/170) had received previous treatment with heparin. Typical-onset HIT usually began 5-10 days after starting heparin. All 73 patients with rapid-onset HIT had previously received heparin (within the last 100 days), and the median onset time was $10.5 \mathrm{~h}$. There were no differences in outcome (thrombotic events or mortality) between the typical-onset and rapidonset HIT groups. Heparin-dependent antibodies fell to undetectable levels at a median of 50-85 days during recovery from HIT. No new episodes of HIT occurred in seven patients with serologically confirmed HIT who received another course of heparin.

\section{Comments}

This study differentiates the temporal aspects of HIT into two groups. In contrast to other drug induced antibodies, heparin-dependent antibodies rapidly fell to undetectable levels. The risk of recurrence of HIT with subsequent brief exposure to heparin is low in patients with undetectable levels of heparin-dependent antibodies. Thrombocytopenia in the ICU is a common phenomenon and causation is often multifactorial, making diagnosis problematic. Unfortunately, identification of this temporal 
sequence of HIT does not help in excluding HIT as a cause of thrombocytopenia in the ICU, and the search for heparin-dependent antibodies is still required

\section{Methods}

15-year retrospective review of medical and laboratory records in patients with serologically confirmed HIT.

\section{Additional information}

\section{References}

1. Warkentin TE, Kelton JG: Temporal aspects of heparin-induced thrombocytopenia. New Engl J Med. 2001, 344: 1286-1292. 